\title{
Freedom, Authority and Care as Moral Postulates: Reexamining Gandhi's Proposal for Ethical Reconstruction
}

Subhra Nag is Professor at the Department of Philosophy, Assam University, Silchar. Her areas of special interest and research are Moral Philosophy, Gender Studies and Philosophical Psychology. She has published several papers in journals and edited volumes.

\begin{abstract}
This paper aims at addressing the points of emphasis laid down by Gandhi in the dispersed frame of his ethical thoughts. Our venture tries to draw the scattered elements of Gandhi's moral thought and ideas in a single frame of analysis and attempts to reflect on the intertwined aspects of them for exploring the potential of an alternative moral stance. Our task is two-fold then: developing a discourse on Gandhi's understanding of ethics, and going beyond the same to examine its significance in a broader context.
\end{abstract}

Key words: Freedom, authority, care, ethical reconstruction.

\section{Prologue}

Gandhi is known well to be one such personage whose life and activities led people, both ordinary and scholarly, to take interest in him for multiple reasons. If his cherished goals are found to be inviting of appreciations on different counts, a good number of critiques took interest in highlighting upon the personal limitations of Gandhi which obstructed him to act on his own prescribed norms. To be honest, an act of easy ascertainment of Gandhi's life-philosophy seems to be difficult enough because of the prima facie simplicity of his thought and ideas on the one hand and the toughness realized in their application to the real life situations on the other. Much of the contemporary scholarship developed on Gandhi has taken up the task of unearthing the foundational roots of Gandhi's religious cum political ideas and ideals. In order to grasp the crux of Gandhi's life-philosophy it is desirable that his beliefs and convictions are given both a holistic and an impartial treatment to the extent possible. There is no doubt that the vast spectrum of the life experiences of Gandhi and his envisioned goals are continuing to provide the researchers with ample scope for developing 


\section{2 / Subhra Nag}

Salesian Journal of Humanities and Social Sciences, Vol. X, No. 2 (Dec 2019)

ISSN: 0976-1861 | 10.51818/SJHSS.10.2019.91-105 | Page: 91-105,

Section: Articles

fresh readings of him. Plenty of those readings intend not only to explore the historical Gandhi but also to map the relevance and implications of Gandhi's thoughts and ideas in a broader global context. The present concern of ours shall form a part of the second trajectory.

Admittedly, Gandhi has played an exemplary role in the formative stage of Indian Polity. Notwithstanding the contentious nature of Gandhi's various personal and the political moves his recommendation for practicing the values non-violence and also love in all ordinary spheres of human life could earn wide acceptability among the peace lovers and the masses in a like manner. Gandhi makes the pursuits of peace and harmony dependent on the culturing of those values that enhance the level of mutual respect and reciprocity in human relations. This particular recommendation of Gandhi could easily obtain global prominence since least alternatives are available with human kind for reaching at the said goal. The inalienability of the value/virtue of non-violence in human condition for a peaceful and harmonious co-existence is, therefore, ascertained beyond doubt. But while the thesis goes uncontested in principle doubts are expressed in various corners in respect of the kind and the extent of its implementation.

This paper aims at addressing the points of emphasis laid down by Gandhi in the dispersed frame of his ethical thoughts. Since Gandhi never attempted to theorize the problematic(s) of moral situations, quite obviously, developing any systemic discourse in this regard would not form a part of his personal cum political agenda. Nevertheless Gandhi was not lacking in clarity in devising necessary decision procedure, which helps in outlining the practical aims of his moral project. In our view, an analysis of the rudimentary state of affairs that has contributed to the construal of the edifice of Gandhi's moral thought shall provide us with a tacit understanding of the theoretical base of his project too. Our venture tries to draw the scattered elements of Gandhi's moral thought and ideas in a single frame of analysis and attempts to reflect on the intertwined aspects of them for exploring the potential of an alternative moral stance. Analyzing the viability of the application of the same in a global context 
also becomes due on our part. As a strategy to do justice to the present concern, we would like to comprehend and evaluate Gandhi's proposed scheme stretching it beyond the level of his personal bias or frailties. Hence, the success and failure of Gandhi in person will not much count to us. In a Popperian ${ }^{1}$ way we would like to see Gandhi's ideas as part of the 'World 3' and hence as independent of the process of the subjective conditioning of him (as the author/creator of the same). This is required for undertaking an objective enquiry into the matter. Our task is two-fold then: developing a discourse on Gandhi's understanding of ethics, and going beyond the same to examine its significance in a broader context.

\section{Edifice of Morality in Gandhi's Understanding}

Looking back and drawing from those cultural, religious or secular belief systems that propagated the philosophy of love, care and non-violence, down the time line of history, have always been a highly rewarding job for the posterity. While bringing the eastern life tradition under the purview of discussion one can take obvious note of the fact that Gandhi is in no way the first thinker to pioneer the practicing values of non-violence, love or compassion in Indian context. In the classical Jaina and the Buddhist traditions such values were made the centre of ethical pursuits centuries back. Even then one finds good reason to read Gandhi because of the significant contribution to the contemporary discourse of non-violence on his part. Gandhi's insistence for practicing non-violence in all ordinary spheres of life and in politics particularly posits a demand for qualitative transformation of the personal and the political self. This attempt of him for setting the values of love and non-violence beyond their usual spiritual and moral ambit has created the occasion for delving deep into serious discussions. A significant part of the contemporary debates on Gandhi primarily centers round the questions of viability and mechanism for materialization of Gandhi's specific agenda for so-called spiritualization of politics.

1 Karl Popper, Three Worlds, The Tanner Lecture on Human Values, Delivered at the University of Michigan, April 17, 1978. 


\section{4 / Subhra Nag}

Salesian Journal of Humanities and Social Sciences, Vol. X, No. 2 (Dec 2019)

ISSN: 0976-1861 | 10.51818/SJHSS.10.2019.91-105 | Page: 91-105,

Section: Articles

Gandhi believes that cultivation of a moral character is mandatory for causing individual and social transformation. Gandhi's understanding of ethics begins by positing the virtues of non-violence along with selfabstinence, non-possession and the like as cardinal virtues of a human being and urges upon their practice at different spheres of human existence. Though all the virtues are equally emphasized by Gandhi - yet in the order of priority he places non-violence as the first one. Love, which seems to be co-adjacent with non-violence, though supreme as value, does not form a part of this list of virtues for him since Gandhi considers love to be the law of life. In The Gospel of Love ${ }^{2}$ Gandhi writes: "I believe in the sovereign rule of the Law of Love which makes no distinctions" (Harijan. 25-5-1947, p. 165). In the same vein he continues:

I cannot claim this as a special virtue, as it is in my very nature, rather than a result of any effort on my part, whereas in the case of AHIMSA (non-violence), BRAHMACHARYA (celibacy), APARIGRAHA (nonpossession) and other cardinal virtues, I am fully conscious of a continuous striving for their cultivation. ${ }^{3}$

For Gandhi, therefore, love is more basic to and precedes non-violence. Whatever be the cardinal virtues of human life, the pursuit for the same on the part of a human individual seems to depend on the fulfillment of certain basic conditions. These conditions serve as pre-requisites to the choice of any moral course of actions - technically called - they are the moral postulates. In respect of Gandhi's ethics it becomes pertinent to ask: what could be the moral postulates in Gandhi's devised scheme then? Analysis of a moral situation where an individual self resolves to act on the principles of non-violence and the like reveals that the subject concerned can do so provided that finds itself free to act so, has the authority to give expressions to one's freedom, and has a loving/ caring concern for the so-called others. Undertaking any course of action in compliance with the moral principles would require an operational frame of freedom, authority and care/love trio. As per our observation

${ }^{2}$ M.K. Gandhi, The Gospel of Love, The Mind of Mahatma Gandhi. http://www.mkgandhi. org/momgandhi/chap 88.htm

${ }^{3}$ M.K. Gandhi, An Autobiography, 204. 
these three have served as the core presumptions of morality in Gandhi's thought frame basing on which Gandhi tries to formulate his agenda for an overall social, political and economic transformation. Whatever values or moral tactics Gandhi has devised as the practicing code for a citizen of a moral polity like satyagraha or passive resistance etc., have derived their sanctions from the three postulates as referred above. While the first two (freedom and authority) are crucial to the constitution of a moral agency, the last one (i.e., care/love) in addition to its constitutive role also offers a characterizing feature to the moral self and defines/sets the limits of a person's obligations towards humanity and the cosmos at large.

Gandhi's understanding of ethics depicts a point of departure from the orthodox conventional understanding of the same. It bears a nonconventional nuance in evolving an inclusionary frame. We have identified the unique features of Gandhi's ethics in its upheld presumptions and in the adopted approach to follow a particular decision procedure. Accommodation of those sets of values and virtues, which are still treated to be feminine in a masculine tradition and left primarily for the pursuits of women, specifies this point of departure in Gandhi's scheme. We hold this view while having the following considerations before us --- the five identified spheres where ethics of Gandhi can claim its maiden status while depicting its affinity with feminist ethics. Gandhi's ethics portrays its novelty:

- In emphasizing a care ethical perspective - exhibited in terms of an empathic concern (Gandhi preferred to use the word love and sympathy instead of empathy to implicate the same nuance). The faculty of care taken either as a disposition or a virtue is well capable of accommodating non-violence and other modes of self control. In addition to which Gandhi's usage (of care perspective) covers the elements of trust, respect and tolerance too.

- In postulating a relational self as the subject or agent of moral actions that finds itself operative in an inter-personal set up of mutuality and interdependence, 


\section{6 / Subhra Nag}

Salesian Journal of Humanities and Social Sciences, Vol. X, No. 2 (Dec 2019)

ISSN: 0976-1861 | 10.51818/SJHSS.10.2019.91-105 | Page: 91-105,

Section: Articles

- In choosing the kind of authority to be exercised by the moral agency the kind to be exercised with or to come from within as distinguished from the authority of domination or authority over.

- In tracing the root of politics in morality implicating in the construal of a moral self vis-à-vis the formation of a moral polity running together.

- The compliance with the above-mentioned four conditions would entail that neither truth nor knowledge can be given an impersonal or context independent treatment in Gandhi. Truth shall, therefore, be personalized and derived through a desirable level of human connectivity and interdependence mediated through love and nonviolence. As he considers truth as the end and non-violence as the means. And speaking on non-violence Gandhi often asserts it to be a kind of infinite love. A moral agent though begins with the exercise of a personal loving relationship yet is capable of stretching it up to the level of infinity through conscious pursuits.

In this venture of ours we have no specific intention as such of digging out any feminist agenda in Gandhi. There are visible points of disagreement on various grounds on Gandhi from the feminist thinkers. Gandhi seems to have sustained lot of puritanical beliefs in respect of woman, sexuality, marital relation, reproductive functions and the like. Taking into due cognizance the biased stance upheld by Gandhi in outlining women's role in men's life, society and the state, we still wish to contend that the core idea and the points of emphasis in Gandhi's moral and political philosophy can find out a closest counterpart in the contemporary discourse of care ethics. Relating care to public/social policy constitutes one prime agenda in care ethics. In Gandhi the same prescription is issued for materializing a participatory democracy. Moreover, his confidence upon women's strength in working out a nonviolent mode of the individual and the collective existence is an indicator of Gandhi's post-conventional attempt for moral reconstruction. What becomes most urgent in Gandhi's proposal is to relate ethics at the personal level to that at the political and the global levels - a pursuit equally targeted by the second generation care ethicists like Joan Tronto, Selma Sevenhuijisen, Michael Slote among others. 


\section{Personal as the Political and the Global: Swaraj, Freedom and Authority}

Gandhi initially begins with the concept of Swaraj and then substantiates the notion with a far more enriching nuance of it by calling it Poorna Swaraj as the goal for India's independence movement. The term Swaraj meaning self-rule or self-government is known to have an indigenous root. As is known, to give independence a common Indian coinage Gandhi brings the concept in use. Swaraj is named so because it is envisioned as a state of civil and political existence which is free from exploitation and domination by the others or the foreign rule. But Gandhi wishes to enrich the prevalent nuance of the concept of Swaraj by stating that it is something more than complete independence. As he says: "My notion of Poorna Swaraj (that is complete self-rule) is not isolated independence but healthy and dignified independence." 4 This independence is, however not exclusive but wholly compatible with interdependence within or without according to Gandhi. ${ }^{5}$

Swaraj is viewed as a counter concept of exploitation both at the national/social and the individual levels. It is equally meaningful and extendable in the international contexts too. Gandhi's view on nationalism is worth mentioning here: "Our nationalism can be no peril to other nations in as much as we will exploit none just as we will allow none to exploit us. Through Swaraj we would serve the whole world." 6 Gandhi scarcely visualizes isolated independence to be the goal of the world states, rather he argues in favour of voluntary interdependence. ${ }^{7}$

This non-exploitative nature of self-ruling prescribed by Gandhi pleads for the formation of a moral polity where all political agenda shall have to merge with the moral. There is another important dimension of Swaraj which finds expression in resisting the abusive nature of authority coming from external forces. Gandhi opines: "Real Swaraj will come not by acquisition of authority by a few, but by acquisition of the all to resist authority when it is abused. In other words, Swaraj is to be attained by

${ }^{4}$ M.K. Gandhi, Young India, March 1931, 51.

${ }^{5}$ Constructive Programme, 1961, 7.

${ }^{6}$ M.K. Gandhi, Young India, April 1931, 79.

${ }^{7}$ M.K. Gandhi, Young India, July 1924, 236. 


\section{8 / Subhra Nag}

Salesian Journal of Humanities and Social Sciences, Vol. X, No. 2 (Dec 2019)

ISSN: 0976-1861 | 10.51818/SJHSS.10.2019.91-105 | Page: 91-105,

Section: Articles

educating the masses to a sense of their capacity to regulate and control authority." ${ }^{8}$

Acquisition of Swaraj as freedom, as a 'liberatory' and self regulatory principle shall require to be based on the acquisition of a moral authority too that comes from within. This authority must have the strength to dissipate self-other distinctions and shall stand against all discriminatory practices. Gandhi reiterates the idea that attainment of Swaraj never closes down at any still point. On the contrary it continues to provide fresh engagements to people for bringing their fellow-beings within its contour - who are still lagging behind - socially, economically, politically, or culturally marginalized sections.

Swaraj is viewed by Gandhi not as a mere political goal to free the nation from foreign ruling. It bears clear prescriptions for individual morality. In answering the question what is moral action? as Gandhi contends, "[a] moral act must be our own act: it must spring from our own will. If we act mechanically, there is no moral content in our act". ${ }^{\prime}$

Gandhi has added further that for an act to be moral it must be free from fear and compulsion and should not be coercive in nature. Gandhi reiterated the belief that moral actions discard all oppressions and discriminations. In the section on Social Ideal in Ethical Religion Gandhi says:

....we have neither practiced nor known ethical religion so long as we do not feel sympathy for every human being. Now we know that higher morality must be comprehensive; it must embrace all men. Considering our relation to mankind, every man has a claim over us, as it is our duty always to serve him. We should act on the assumption that we have no claim on others. ${ }^{10}$

\footnotetext{
${ }^{8}$ M.K. Gandhi, Young India, January 1925, 41.

${ }^{9}$ M.K. Gandhi, Ethical Religion, chapter 5, http://www.mkgandhi.org/ebks/ethical.pdf

${ }^{10}$ Ibid, chapter 7.
} 


\section{Women, Non-violence and Care}

Gandhi remarkably contends that women have a better proneness to act on the virtue of non-violence in comparison to men. Gandhi was in all likelihood deeply convinced by the inherent moral potency of women to extend love and care for the others in their usual psychic pattern. Gandhi expresses his stance quite categorically in his address "To the Women of India", in Young India, 10 ${ }^{\text {th }}$ April, 1930:

In this non-violent warfare, their contribution should be much greater than man's. To call woman the weaker sex is a libel, it is man's injustice to woman. If by strength is meant brute strength, then, indeed, is woman less brute than man. If by strength is meant moral power, then woman is immeasurably man's superior. Has she not greater intuition, is she not more self-sacrificing, has she not greater powers of endurance, has she not greater courage? Without her, man could not be. If non-violence is the law of our being, the future is with women. ${ }^{11}$

The statement of Gandhi as expressed above shows that the traits of human which would come to characterize moral power in Gandhi's view are intuition, self-sacrifice, endurance and courage (to bear with?). The place of reason is not of much importance here. Gandhi does not accord to the view that reason is either the superior or the only faculty leading to human excellence. There is no hesitation, therefore, on our part to argue that the proposed ethics in Gandhi can quite justifiably be termed as nonrationalist.

In Bhikhu Parekh's observations we see a confirmation of our contention. As Parekh observes:

Although he took a rather narrow view of reason, he rightly argued that it was not the only valuable or even the highest human faculty. This enabled him to cherish and champion faculties, modes of cognition, forms of knowledge, and styles of reasoning and discourse that are often devalued in a narrowly positivist world-view, and to create a theoretical and moral

${ }^{11}$ Collected Works of Mahatma Gandhi, Vol. 49, 57. http://www.gandhiheritageportal.org 
Salesian Journal of Humanities and Social Sciences, Vol. X, No. 2 (Dec 2019)

ISSN: 0976-1861 | 10.51818/SJHSS.10.2019.91-105 | Page: 91-105,

Section: Articles

space for traditions, intuition, collective wisdom, and feeling. ${ }^{12}$

Justifying the matter why Gandhi has taken recourse to a non-rationalist theory of rationality Parekh continues:

Gandhi redefined the concept of citizenship, and stressed the ideas of political participation, self-discipline, concern for others, and personal responsibility that are often ignored in liberal writings. ${ }^{13}$

Gandhi's emphasis on 'concern for others' and 'personal responsibility' amidst all the other basic elements of moral life depicts a paradigmatic shift from the right based ethics as outlined in liberal tradition to that of ethics of responsibility. In enormous writings of him Gandhi kept on reiterating the fact that one can follow the course of morality only by ensuring the good and well-being of others. The latter can materialize - provided - one develops a loving or a caring concern for others and is capable of sustaining the belief in inherent goodness of human nature. The faculty of care can take an ethical lift from the psychological state of sustained unwillingness to hurt or harm others. Gandhi clarifies this point in his writings - I am not Anti-British - by stating that he would not like to cause harm or hurt people even when they would have enmity or hatred toward him. He relies on the contrary on the force of love as the force of soul or truth which can conquer the opponents' mind. ${ }^{14}$

Ordinarily viewed love and non-violence can accompany care or follow from care (as a psychic pattern) where as it seems a bit difficult to start with love. It would be difficult for a person to start by loving the entire cosmic community (of which a very small part will be accessed by the moral subject) though it would be comparatively easy for a being to choose a caring pattern for actions in respect of all appropriate moral objects, both visible and invisible. In a given situation care can be very basic to any psyche whereas love and non-violence need culturing. Why or how should I love others or extend my love for the greater community

${ }^{12}$ Bhikhu Parekh, Gandhi, A Very Short Introduction, (New York: Oxford University Press, 1997), 118-119.

${ }^{13}$ Ibid, 118.

${ }^{14}$ M.K. Gandhi, I am not Anti-British. http:/ / www.mkgandhi.org/momgandhi/chap 65. 
- of which a very meager part is known to me? Even if I do not have any direct answer to the question I may end up by stating that I have no other better option but to choose for it since I see my completion in that. One step ahead would be to choose it voluntarily on moral grounds. Gandhi, however, has taken an exception to this ordinary understanding of carelove dichotomy. Love, according to him, is inherent in human nature and hence, needs no conscious effort for cultivating. That is to say, Gandhi makes love basic to human nature in a manner in which the care ethicists presumes care as basic to woman's psyche. But drawing it beyond the personal limit shall require extra effort.

Gandhi's confidence upon woman's caring nature goes well with the contention that the faculty of care is seen to be prominent in woman's psyche because of her conventional upbringing. This point was well recorded in the moral accounts of the care ethicists like Gilligan ${ }^{15}$ (1982) Noddings ${ }^{16}$ (1982) and others. Gandhi confirms the same in admitting the fact of woman's proneness to act in a non-violent manner.

Referring to the matter Parekh says:

"He wondered if and how it was possible to be profoundly at peace with oneself, other human beings, and with one's natural and social environment, how to live without hurting and harming a single living being and even wishing to do so." ${ }^{17}$

\section{Does Gandhi's notion of 'care' comply with the feminists' understanding of the same?}

The term 'care' has been extensively used by the care ethicists to mean a disposition, a value, a virtue, as a practice and as an overlapping concept of all these nuances taken together. Sara Ruddick has pointed out three distinct but overlapping meanings of care in use of the care ethicists. Care

15 Carol Gilligan, In a Different Voice. Psychological Theory and Women's Development, (Cambridge,: Harvard University Press, 1982).

${ }^{16}$ Nel Noddings, Caring: A Feminine Approach to Ethics and Moral Education, (Berkeley: University of CA Press, 1982).

${ }^{17}$ Parekh, 112. 


\section{2 / Subhra Nag}

Salesian Journal of Humanities and Social Sciences, Vol. X, No. 2 (Dec 2019)

ISSN: 0976-1861 | 10.51818/SJHSS.10.2019.91-105 | Page: 91-105,

Section: Articles

can stand for (i) an ethic defined in opposition to justice; (ii) a kind of labour and (iii) a particular relationship. ${ }^{18}$

Virginia Held's recommendations in this regard are for taking care as a form of labour which also can be visualized as an ideal. To her, "clusters" of practices and values may go by the name of care. ${ }^{19}$ Held specifies the central focus of care on "the compelling moral salience of attending to and meeting the needs of particular others for whom we take responsibility." 20

More contemporary attribution to this care discourse with political implication is brought forward by Joan Tronto. Care is understood by her as "species of activity that includes everything we do to maintain, contain and repair our 'world' so that we can live in it as well as possible. That world includes our bodies, ourselves and our environment." ${ }^{21}$ Care is taken more in the sense of practice by Tronto. She further identifies four sub-elements of care that can be understood simultaneously as stages, virtuous dispositions, or goals. These sub-elements are: attentiveness, a proclivity to become aware of need; responsibility, a willingness to respond and take care of need; competence, the skill of providing good and successful care and responsiveness, consideration of the position of others as they see it and recognition of the potential for abuse in care. Tronto has addressed cultural variations in her account of care and extends the same beyond family and domestic spheres. ${ }^{22}$

Some scholars attempted to read Gandhi's ideas and activities in the light of the Care Theories. A noteworthy attempt is of Joseph Kupfer's ${ }^{23}$

${ }^{18}$ Sara Ruddick, "Care as Labor and Relationship", in Haflon and Haber (eds), Norms and Values: Essays on the work of Virginia Held, (Lanham, MD: Rowman \& Littlefield, 1998), 4.

${ }^{19}$ Virginia Held, The Ethics of Care, (NY: Oxford University Press, 2006), 36-40.

${ }^{20}$ Ibid, 10.

${ }^{21}$ Joan Tronto \& Bernice Fischer, "Toward a Feminist Theory of Caring", in Emily. K. Abel and Margaret K Nelson (eds) Circles of Care: work and identity in women's lives, (Albany, New York: State University of New York Press, 1990), 36-54.

${ }^{22}$ Joan Tronto, Moral Boundaries: A Political Argument for an Ethics of Care, (New York: Routledge, 1994), 126-31.

${ }^{23}$ Joseph Kupfer, “Gandhi and the Virtue of Care", Hypatia 22, 3(2007): 1-21. 
who bases his reading on Richard Attenborough's film Gandhi (1982). Kupfer claims that Gandhi is a moral exemplar for whom care was the dominant virtue. Gandhi's pledge for non-violence undoubtedly displays the element of care. A few other characteristic features of care ethics like that of owning responsibility, responsiveness to need, honouring relationship and the factor of mutual dependency are also noticeable in Gandhi's contention. Though Gandhi does not specifically mention care as any distinct virtue or aims at giving it the central place in ethics yet the pattern of morality envisioned by him bears this indication that he pays much value to it. What lies at the core of his philosophy is love, not exactly care. Even then there is good logic to admit care as a postulate in Gandhi's ethics, since the conceptual frame of Gandhian ethics like that of care can corroborate a huge range of human emotions, human sensibility and also ethical injunctions. Gandhi has made room for all these elements in his understanding of morality that premises itself on universal love. Love is an encompassing concept for him from which the values of care, concern, respect, trust and tolerance emanate in a very natural way. Gandhi considers love as a cohesive force that binds not only people but also their families, communities and nations. Gandhi's ethics prescribes a common decision procedure for both people and the nations - "what is true of families and communities is true of nations." ${ }^{24}$ Hence, the way in which implications of care are drawn in the sphere of international politics, in preventing war of violence, and pursuing peace, in a similar fashion Gandhi's strategy to fight back violence at the personal level with love and respect bears implications for national and international politics too.

Kupfer's observation proceeds to situate virtue of care in Gandhi's ethics in the following way: Care as the basis of a coherent public stance shaping Gandhi's political decisions and public policy. Gandhi in person works on the 'motive of benevolence with subsidiary virtues, such as attentiveness and responsiveness'. That the virtue of care is structured by the building blocks of the care perspective: responsibility and need, relationship and mutual dependency, context and narrative, each of ${ }^{24} \mathrm{Ibid}$, The Gospel of Love. 


\section{4 / Subhra Nag}

Salesian Journal of Humanities and Social Sciences, Vol. X, No. 2 (Dec 2019)

ISSN: 0976-1861 | 10.51818/SJHSS.10.2019.91-105 | Page: 91-105,

Section: Articles

which has received due emphasis in Gandhi's life and activity in personal and political spheres. ${ }^{25}$

What we intend to state here is simple enough to admit. Gandhi has understood love as very basic component of human nature which plays a decisive role in fixing human responsibility. Care without love may not be an impossible state of affair in ordinary parlance but Gandhi thinks otherwise. Care for him is a necessary dimension of love. It is grounded in love. Attentiveness, responsiveness to others' needs, owning responsibility and the like are addressed in Gandhi from the perspective of care intertwined with love. What Gandhi in actuality argues for is to base morality on the solid grounding of not simply care but loving care.

\section{Ethics/Morality as Religion}

True morality according to Gandhi is inclusive of religion. Morality, as initially Gandhi opines, cannot be observed without religion. But immediately he goes for altering the utterance by stating that morality should be observed as religion and that there is nothing wrong in calling morality a religion. ${ }^{26}$ Drawing the sanction sof morality from religion seems to be nothing exceptional in the tradition of religious ethics. But Gandhi's interpretation of morality as realm of beliefs, knowledge or conduct that can be observed as religion sounds novel. Two things are important to be kept in mind: (i) Gandhi is no believer in any personal God but to him truth is God and (ii) Gandhi follows a faith tradition where confined institutionalized practices carry lesser value. In view of the stated facts it becomes necessary to understand the universal message of humanity that urges upon developing human bonding in a most religious manner. Gandhi's writings in The Ethical Religion depict a structured attempt on his part to flourish the idea that religion oblivious of or falling short of morality is no religion at all. What follows is that the ultimate sanction of religion comes from morality and not the other way around.

${ }^{25}$ Ibid, 4-5.

${ }^{26}$ M.K. Gandhi, Ethical Religion, Chapter 5, www.mkgandhi.org/ebks/ethical.pdf 
Freedom, Authority and Care as Moral Postulates .. / 105

Salesian Journal of Humanities and Social Sciences, Vol. X, No. 2 (Dec 2019) ISSN: 0976-1861 | 10.51818/SJHSS.10.2019.91-105 | Page: 91-105,

Section: Articles

\section{Conclusion}

All the points we jotted down above are not exhaustive enough but yet indicative of showing that Gandhi's ethics has taken a departure from the conventional ethics. The passage of transition from personal to collective or from private sphere to public sphere of morality follows no utilitarian path here. On the contrary the recommendations come for the adoption of the virtues of ethical approach to moral issues where motive, intention and consequences all equally matter in a globally personalized frame. 